well afford to provide its inventor with unlimited resources and promise him a prize in case of success, running into the millions."

But the Government saved $\$ 970,000$ and got a machin which eclipsed the most sanguine hopes. The Board of the funds which made possible the contract with the
Wrights, Congress having failed to authorize the 1908 Wrights, Congress having failed to authorize the 1908
aeronautical estimate of $\$ 200,000$.

Twenty-two bids in all were received within the tim limit. This is the first time they have been published. They were as follows: $\mathbf{5 , 4 5 0}$ A. E. Moline....... $\$ 850$ \begin{tabular}{ll|lr} 
Brown \& Swingle... & $\mathbf{5 , 4 5 0}$ & A. E. Moline........ & $\mathbf{1 , 3 8 9}$ \\
R. G. Dressler..... & $\mathbf{5 , 0 0 0}$ & E. H. Young....... & $\mathbf{5 , 0 0 0}$
\end{tabular}

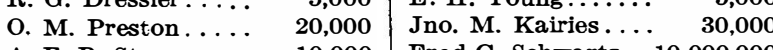
$\begin{array}{lll}\text { A. F. P. Stenzy ... } & 10,000 & \text { Fred C. Schwartz...10,000,000 } \\ \text { W. R. Gordon \$40, } \$ 50 \text { and } & \text { Wm. Harper, Jr... } 20,000\end{array}$ \begin{tabular}{l|l}
$\$ 65$ per pound & Frank \& Hedden Co. 500
\end{tabular} $\begin{array}{llll}\text { L. J. Brown ....... } & 15,000 & \text { Chas. B. Nichols ... } & 52,568\end{array}$ $\begin{array}{llll}\text { John F. Cavanaugh. } & 55,000 & \text { A. W. H. Grieppe .. } & \mathbf{2 5 , 0 0 0}\end{array}$ \begin{tabular}{c|lr} 
J. J. P. Boatman, 7,000 per & James F. Scott..... & 1,000 \\
ton lifting capacity, 1-10 tons & A. M. Herring.... & 20,000 \\
\hline
\end{tabular} \begin{tabular}{c|cc} 
ton lifting capacity, 1-10 tons & A. M. Herring...... & 20,000 \\
Chas. M. Wanzer...\$1,000,000 & Wright Brothers... & 25,000
\end{tabular}

One bidder stated his machine would sustain itself in the air without any machinery whatever and ascend from any ordinary place in calm or storm. Only 30 days were required by one man to deliver his machine, while another thought five years ought to be allowed, as it was a big undertaking, this first production of something the world had never seen. One of these, whose bid was extremely low, set forth his specifications simply as follows:

"Speed 100 miles per hour (arc planes silk, aluminum bands, steel wires and paper). Surface of airplanes two $7 \times 11$ feet, three ground wheels, two guyre scope wheels, one blower, speed 1,000 revolutions per minute, engin and everything complete, ready for flight with two men 700 pounds.'

Another offered an "airship carrying 15 men at a speed of 40 miles an hour, fuel for 3 days, with a 25 horse-power motor." This is rather better than the record up to 1919 , but, as the bidder wrote on his bid, "Bei Gott sind alle Dinge meglich."

Of these offers three were accepted:

$$
\begin{aligned}
& \text { Wright Brothers } \ldots \ldots \ldots \ldots \ldots \ldots \$ 25,000 \\
& \text { A. M. Herring's . . . . . . . . . 20,000 }
\end{aligned}
$$

None of these bidders save the Wrights have ever flown power machines, so far as is known, and only one airplane was ever delivered for test, though A. M. Herring obtained several extensions of time. Scott was not awarded a contract. The Wright flights of July 27th and 30th 1909 were not the first, however, under the contract, for on September 30th, 1908, official flights were begun at Fort Meyer, near Washington, to fulfill the conditions imposed in the contract. The sad death of 1st Lieut. Thomas E. Selfridge, the passenger, and the serious injury to Orville Wright, the pilot, as a result of a 75 -foot fall during one of the trials, postponed further flights for that year and necessitated a nine months' extension of time. The death of Lieutenant Selfridge, whose monument may be seen at Arlington Cemetery, was the world's first airplane casualty.

While Orville was starting his flights in the Army airplane in September, 1908, Wilbur Wright was flying in France. On the last day of the year he made a record of 77 miles in 2 hours, 20 minutes, which stood until August, 1909

After the delivery of the Army airplane on July 30th, 1909, Orville Wright went to Germany, where a company had been formed similar to those in France and England. Wilbur Wright remained to teach the United States' first Army fliers, 1st Lieutenants Frank P. Lahm and B. D. Foulois. In addition to the formation of the
world's first military aviation force, there are some other reasons why July, 1909, should be remembered in the flying world. Bleriot, the lamp manufacturer; the automobile racing driver, Henry Farman Hubert Latham; Delagrange; the airship mechanic Louis Paulhan, and Roger Sommer were daily making new individual records in France, though none yet F.S. Cody, an American of the British Isles, was making short hops in England as was A. V. Roe, originator of the now famous Avro training machine.
On July 25 th, Bleriot made the first airplane crossing of the English Channel from Calais to Dover, in his own famous monoplane -31 miles in 40 minutes. Latham
made his second attempt to cross the channel on July made his second attempt to cross the channel on July
27 th and for the second time landed in the water, though within two miles of his goal.

Glenn H. Curtiss, on July 5th, was flying for the benefit of the citizens of New York at the world's first open air meet, at the world's first club aviation field, on the old

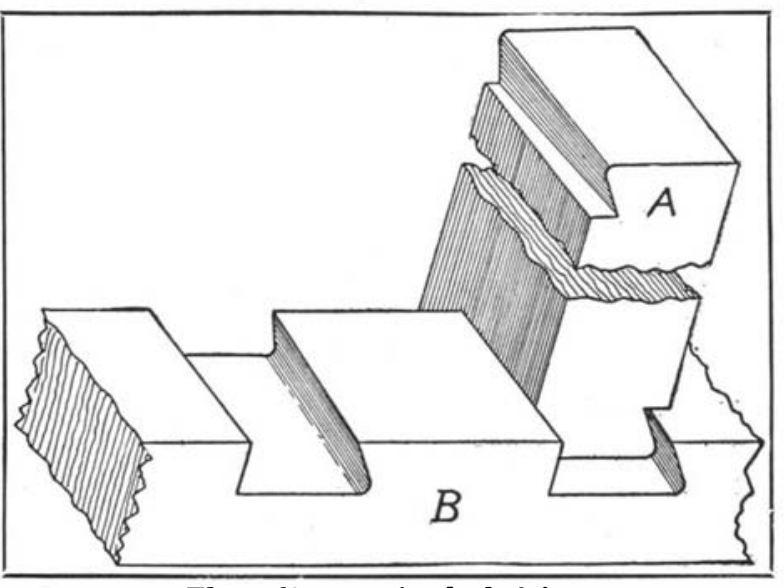

The self-centering lock-join

A, Joist or stud. B. sill or plate. The tenons are oppositely faced at the ends of the joist or stud. This obviates any right or left so that either end will fit into the designed mortise.

Morris Park racetrack, which had been leased by the Aeronautical Society, organized to give embryo fliers

place where their machines could be built and tried.

Charles F. Willard, the airplane manufacturer, began his career in 1909 and it was at the Aeronautical Society's field that he built his first plane. It was unfortunate of the exhibition but that was the fault of the shed. In this month Curtiss forever established his reputation as an airplane pilot when, on the 16ih, he flew 52 minutes and covered 25 miles in the Aeronautical Society's airplane at Mineola, his longest flight to that date. The previous year on the 4 th of July he had won of a little more than a mile in his biplane the "June Bug"

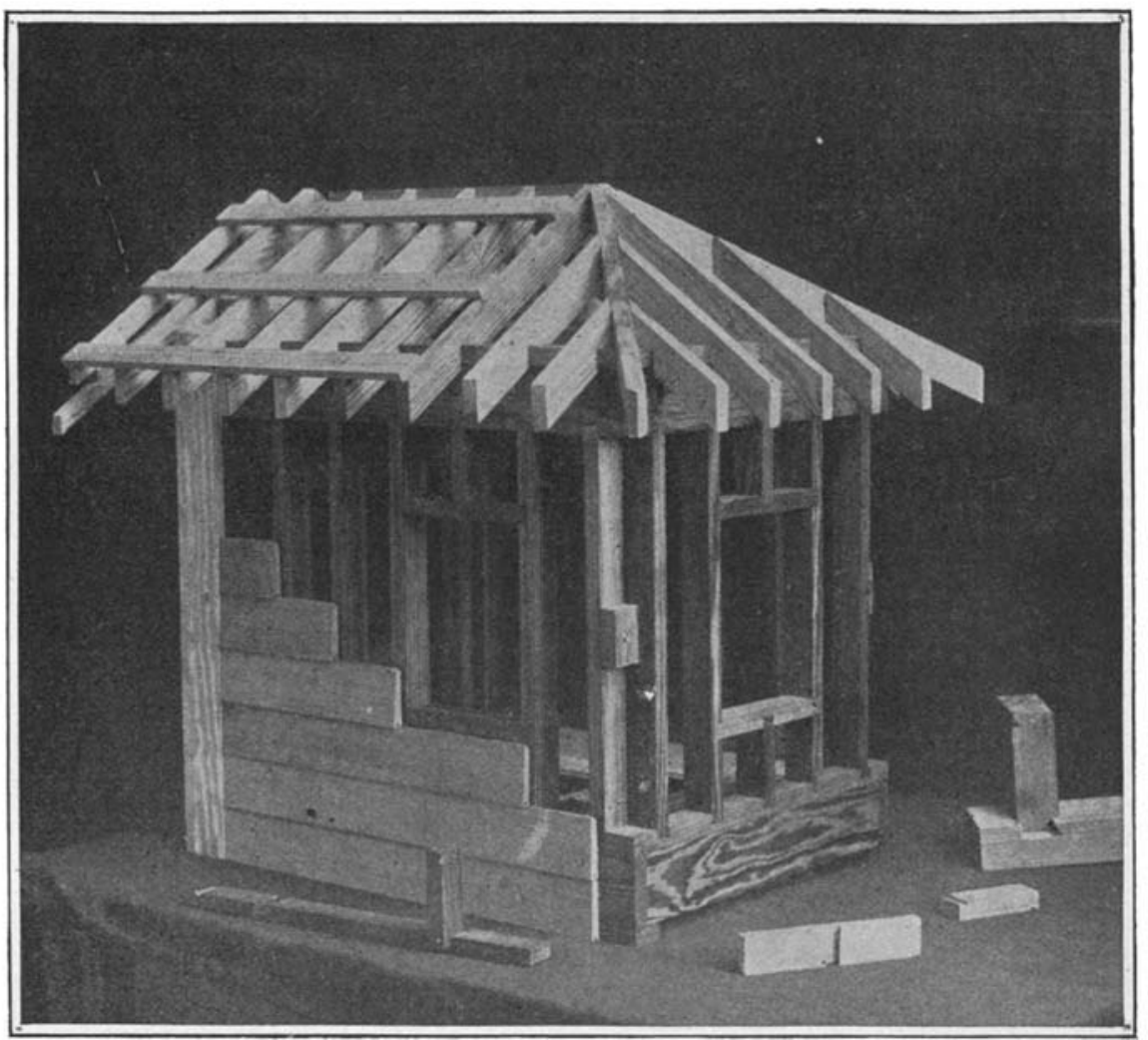
Model of a section of standardized construction consisting of elements of definite
dimensions which can be assembled with one-third the usual number of nails. Only one tool is required-a hammer

and the 25-mile flight gave him the trophy for the second time. The next year.by a flight of $74 \frac{1}{2}$ miles without stop he came into permanent possession of the cup. It might be appropriate to mention here that while the Wrights were delivering their first Army airplane to a world power, Curtiss was delivering the first commercial machine of record to the Aeronautical Society which had been contracted for the year before while Curtiss was Alexander Graham Bell's Aerial Experiment Association.
After his 25-mile flight, Curtiss started on the instruction of Charles F. Willard, one of the society's members, who, under the terms of the purchase order, was one of the two selected to be taught the art of aerial locomotion. Thus was inaugurated the first flying school in the world. All over the United States there was great activity. Every youth of mechanical trend of mind was reading the few aeronautical magazines of the world and building airplanes of his own or some one's else design. There supply not for aviation

Many old timers in aeronautics have dropped out and gone their unknown ways and some have died in traveling the new way. Others have continued, of whom many have achieved prominence. Lieutenant Foulois, now Brigadier General, was the first Chief of Air Service of the American Expeditionary Forces; Lieutenant Lahm, Third Army, A. E. F.; Major C. McK. Saltzman is now Brigadier General.

Colonel C. deF. Chandler, head of the Balloon Section of the A. E. F., was the first Army dirigible pilot and one of the very earliest officers to learn to fly the Wright airplane. Major George O. Squier, the second United States officer to have a flight in an airplane, is now Major-General and Chief Signal Officer. These men Army's first plane. Colonel T. D. Milling, Lieutenan Milling in 1911, when he was one of the army officer detailed to learn to fly the Wright, was Chief of Ai Service of the First Army A. E. F., Colonel H. H. Arnold also a member of the first group to learn to fly, was assistant Director of Military Aeronautics in Washington

Curtiss, Willard, Wright, Burgess, Seely, Kirkham, Leo Stevens, Glenn Martin, Spencer Heath and other old-timers have all done big things in the recent tremendous development of aviation. They and thei successors may be counted upon to stick by the ship of what Congress may or may not do.

\section{Fabricated Lumber and the Housing Problem} By Robert G. Skerre

THE housing problem is countrywide in its reach various authorities be corland of ours who cannot find the accommodations they desire or to which they are accustomed. This seriously menaces our accustomed. This seriously menaces our unrest and unquestionably cuts down the efficiency of our citizenry.

To make matters worse, the price of labor has recently been raised a substantial percentage. Similarly the cost of structural materials is mounting more or less in pro-
portion. How, then, can the situation be portion. How, then, can the situation be
met without imposing a needlessly heavy met without imposing a needlessly heavy
$\operatorname{tax}$ upon all concerned? Has American ingenuity anything to offer in the way of immediate relief? Is there anything distinctly novel in house building which will help measurably to meet the present need which we are informed are likely to prevail which we are inform
for years to come?

for years to come?
The structural steel worker-and thi incidentally includes the designer or architect-has been achieving many of his amazing results in the last decade or so by reason of the standardized materials turned out at the steel mills. Going a step farther, these plants have cut and prepared their plates, angles, beams, etc. so that only a minimum of labor would be required to assemble these units at the building site. In a kindred way the fabricated ship has come into being. Why, then, should standardized lumber parts not find a corresponding and helpful field this question in a thoroughly practical fashion.

Engineering cunning and practical experence have come to the rescue in the shape of cut-toeconomically-lor which is so cleverly machined at the can be assembled with a marked saving in time and outlay Not only that but, within some limits, the house builders can be recruited from the very house builders can be recruited from the very commonest of laborers. The significance of this becomes carpenter, so the borts in mind that the first-class (Continued on page 117) 
A Terminal on the Jersey Flats (Continued from page 103)

will likewise be ample. The present pierhead and bulkhead lines, as established by the New Jersey and the Federal authorities, are, respectively, roughly at the outshore three-quarters and at the mid-section Because of the physical nature of the harbor bottom and the contour, it would not be feasible to develop the property without a modification of pierhead and bulkhead lines. In the absence of such changes, it would ment to dredge the entire area from thepresent channel back to the existing pierhead line. Since this would involve an expenditure of some millions of dollars, while the space in question can be more effectively utilized by bulkheading and filling, the space for actual navigation allowed by the project is ample.

In the plan therefore the coal bunkers In the plan there op bulkhead line, outshore of the present pulkhead line, The ship-repair plant is located at the northerly edge of the property, adjacent to the oil works and the National Docks, not only because it will lead to less congestion of traffic in the dock slips, but also in order to make use of existing rock foundations for the graving dock. The piers and slips on the southerly edge of the property were designed adjacent to a wide channel and also with reference to the sub-surface rock so as to minimize the cost of excavation. However, the presence of this rock makes it possible to erect multi-story pier sheds, specially designed, for expediting the loading of outgoing vessels. The inshore slip is to be used for lighterage and bargecanal business requiring less depth of navigable water.

In the drawing herewith, a perspective view of the completed development is given. Commencing at the upper lefthand (southwest) corner are seen the rail-
road roundhouses, with space for a miniroad roundhouses, with space for a minimum of 50 locomotives. Next, coming east, are the barge and lighter docks, consisting of two piers with landings on both sides and bearing large varehouses. Dredging to a depth of 30 feet would he practicable here if necessary. The regular steamship piers are next, eastward toward the open bay; of these there are three of 1,500 feet each, with six to eight-story
superstructures, and two open pirrs. All

these have slips on both sides.

Coming on to the northeast corner is the fuel-oil supply station, containing three tanks, each with capacity of several million gallons, connected by circulating pipes to ship berths over a large wharf fro:atage; also heating and lubricating oil plants. The all-important coal equipment occupies the east frontage, with 2,400 lineal feet of pockets. The system here is an elaboration of that at Newport News,
which has already been described in these column

Next along the east frontage, to the northward, is the carfloat terminal, which connects directly with the great freight this process of manufacture, short-length car classification yards extending backward pieces of lumber can be worked up into the entire two miles of the tract. There a higher grade of material at the mill; are five double slips for the car floats, a and transportational charges and wastage new feature being trackage on long piers at destination are greatly reduced because between the slips to permit of storage of the shipping weight is cut to a minimum cars to prevent delays. Next ccrme the and the struct

truck ferries and transfer sheds for ac- to a nicety. received direct via dray can be transferred furniture owes its strength fundamentally to all parts of the harbor. Direct con- to the skilful fashion in which its parts were nection will be established between trucks joined together by dovetailing. The readyand cars, with roadways, ramps and over- to-assemble, standardized lumber is in the head bridges provided for all vehicles, and main similarly united, to just that extent

grade-crossings wholly eliminated.
At the northeast corner are the grain elevators, with special provision for hand- do this preparatory work have a daily ling barge traffic and extensive pier sheds capacity of 10,000 feet of finished product and warehouses for use of craft from the as against 650 to 700 feet-the work of up-state canals Next on the northerly the ordinary carpenter during an ork of side is the ship repair plant, extending day. The lock joint employed is of a \begin{tabular}{l|l|l|} 
to the oil works on the mainland. & special design consisting of a tapered tenon \\
Adjoining the railroad tracks near. the & which enters a dovetailed, tapered dado.
\end{tabular} outer extremity of the track at the north-
(Continued on page 119)

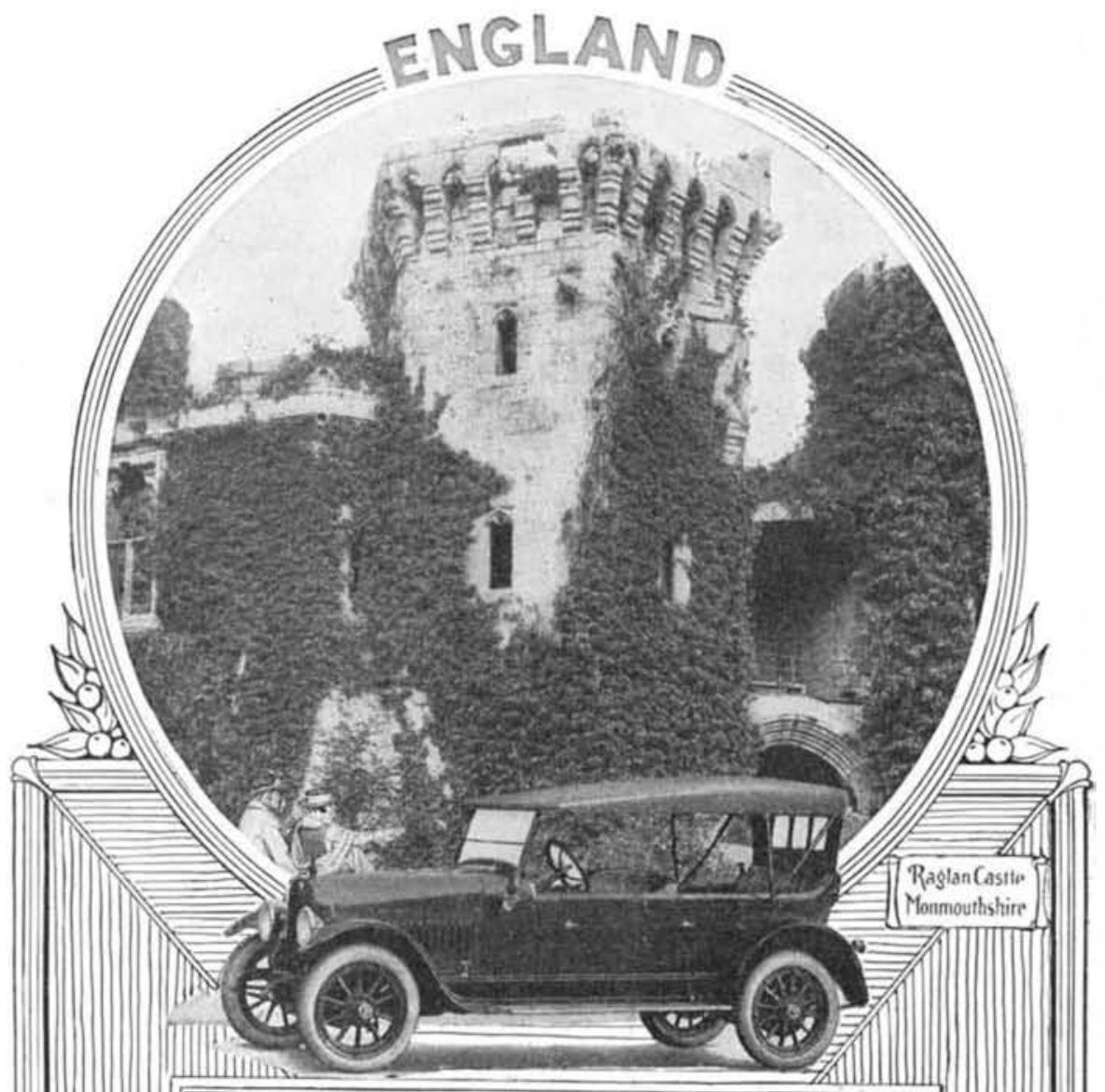

Song wear can only be proved by lony experience. The makers of the Thadson cur, for instance, have used

\section{Pantasote}

exclusuely as standard equipenent on Tudsan cars conti uously since 191\%.

Oto top material is too good for your car.

$\begin{array}{ll}\text { PIERCE ARROW } & \text { REO SIX } \\ \text { SCRIPPS BOOTH } & \text { KISSEL } \\ \text { PAIGE LINWOOD } & \text { WHITE } \\ \text { LOCOMOBILE } & \text { COLE } \\ \text { PREMIER } & \text { CHALMERS } \\ \text { HUDSON } & \text { COLUMBIA } \\ \text { MERCER } & \text { CADILLAC }\end{array}$

Look for Pantasoote LLbel inside the top-it protecta you
againat pubontution wbich it not uncommon.

The Pantanule Cumpanty

Bowking Eneen Building

Tlav York Cily 
Fabricated Lumber and the Housing Problem (Continued from page 117)

These tenons are on the opposite faces at the ends of the studding, joists, etc., and,
therefore, there is no right or left to be considered-either end will fit the designed mortise. Because of this feature assembling becomes foolproof. Probably no better evidence of this is
needed than the fact that very large quantities of this standardized lumber quantities of this standardized lumber laborers were unskilled and could neither read nor write. The different parts were painted a distinctive color on one end, and similar colors were marked on the blue-
prints which designated the locations for the pieces. In this simple fashion the peons were guided, and the structures were reared correctly and with creditable speed. As a matter of test, buildings of this lumber have been erected in this country by blindfolded mechancis; and recently a string of houses seven miles long was p
up of this novel, standardized material.

up of this novel, standardized material.
During our participation in the European During our participation in the European
conflict, the United States Government conflict, the United States Government
employed this lumber extensively for wa construction work both here and abroad because of its time-saving, freight-reducing characteristics. Today, the Federal an-
thorities have released their exclusive thorities have released their exclusive claim upon the system, and the home
builder, face to face with the problem of builder, face to face with the problem of making his dollars go as far as possible can now have recourse to this fruit of
native cunning. Further, this new order of standardized product makes it possible thanks to the conservation effected at the saw mill, to utilize much lumber which would be counted largely a loss at the lengths and marred by natural defect Therefore, we have in this example of efficiency, brought to a climax through stress of conflict, a commodity which will do much to solve the nationwide housing problem and, incidentally, lead to many material economies and enduring benefits. Every $\log$ will henceforth give. a full

Disposing of Ashes with Steam (Continued from page 111)

half of the pipe sections. After the pipe line has been in service for the removal of several thousand tons of ashes it may be turned over so as to present a new wearing surface, and at the same time the liners are renewed. At the point where the steam is injected special provisions are made to take care of the wear, which at such points is a maximum because the stream of ashes must make a sharp turn to the vertical direction. The same is true of the elbow pipe. Here special liners are provided of wear-resisting material and the parts are so arranged that they may be readily renewed. Each plant has its own petion will not fit all cases. Special joints and steam units are provided, in some of which the elbow instead of making a short turn consists of a long sweep.

One of the important advantages of this system of disposing of ashes lies in the fact that boiler rooms are kept clean. In fact dust-free boiler rooms prove a considerable inducement when hiring new men.

\section{The Craters of the Moon}

(Continued from page 114)

groups, under the names walled-plains, mountain-rings, ring-plains, crater-plains, craters, craterlets, and crater-pits.

Whether or not all of these various forms have been produced in the same way is a question. At present there is no consensus
of opinion as to their origin. Many theories have been advanced, several of which ories have been advanced, several of which
in brief outline follow. The ice theory, suggested perhaps by moon to an ice surface seen from a distance, supposes that formerly the moon was covered with pools of water kept in the liquid condition by heat from within. The water evaporated, but, on account of the low temperature of the surrounding atmosphere, was quickly deposited as snow,

This theory has little to commend it. t does not account for the central peaks, so of ten found within craters, nor for the teepness of the crater walls. If composed of ice, the walls would have flattened out long ago in the process of glacial flow. A second theory is based upon tidal
action. Just as the moon causes tides action. Just as the moon causes tides upon the earth, so the earth produces an
ebb and flow in all parts of the moon which ebb and flow in all parts of the moon which are not perfectly rigid. At some stage in its history the moon is supposed to have been in a molten condition. According
to the tidal theory, as the moon cooled, a to the tidal theory, as the moon cooled, a crust began to form on its surface, and, while there were still holes in it here and there, tidal forces caused an ebb and flow of the magma. At each high tide the lava rose through the opening and spread for some distance over the crust and then reeded as the tide ebbed, but, as a result cooling and hardening, some of the magma remained on the surface in the each subsequent tide more material was deposited, until a typical circular crater wall was formed. As the opening became smaller, and the magma cooler and thicker, a central peak may have been built up. It is quite possible that some of the craters may have been formed by this process, but it is difficult to see how such complex system of overlapping and our third figure-can be accounted for? in this way.

A third theory is based upon the marked resemblance between the lunar craters and mud or mortar. This may be called the meteorite theory, or, in its modified form, the satellite theory. The earth in its journey through space encounters thouthese, as they dash into our atmosphere, are burned up by friction, and we see them as shooting stars, but many are large enough to pass completely through the atmosphere, and actually strike the earth. argest weighs between six and seven hundred pounds.

The moon also must be struck by meteoric matter, and, according to this theory, what we see on the moon is the effect of such a bombardment at the time when the moon's surface was just beginning to solidify. If the craters were really formed in this way, the masses which produced them must have been much larger than any meteorites with which we are familiar. Judging from the size of the craters, several of the masses must have been somewhere about one hundred miles in diameter, that is about the order of size of the largest of the asteroids, and there must have been at least 50,000 with a diameter greater than half a mile.

The meteors which strike the earth are moving, singly or in swarms, around the sun and have an average velocity of 26 miles a second. Now meteors large enough produce such effects as we see upon the moon, and moving with a velocity of even so much heat that not the slightest trace of the impact could possibly remain. Not only would the meteor itself be completely melted, but also any crater walls that it might form. Moreover, meteors moving in this way would strike the surface at all angles and if craters could be formed, the greater number of them would formed, the greater number of them wo To overcome these two objections $i$ this theory, it has been suggested that formerly the earth may have been surrounded by a swarm of small satellites, similar to those which form the ring around Saturn. The moon would be in swarm and moving at approximately the

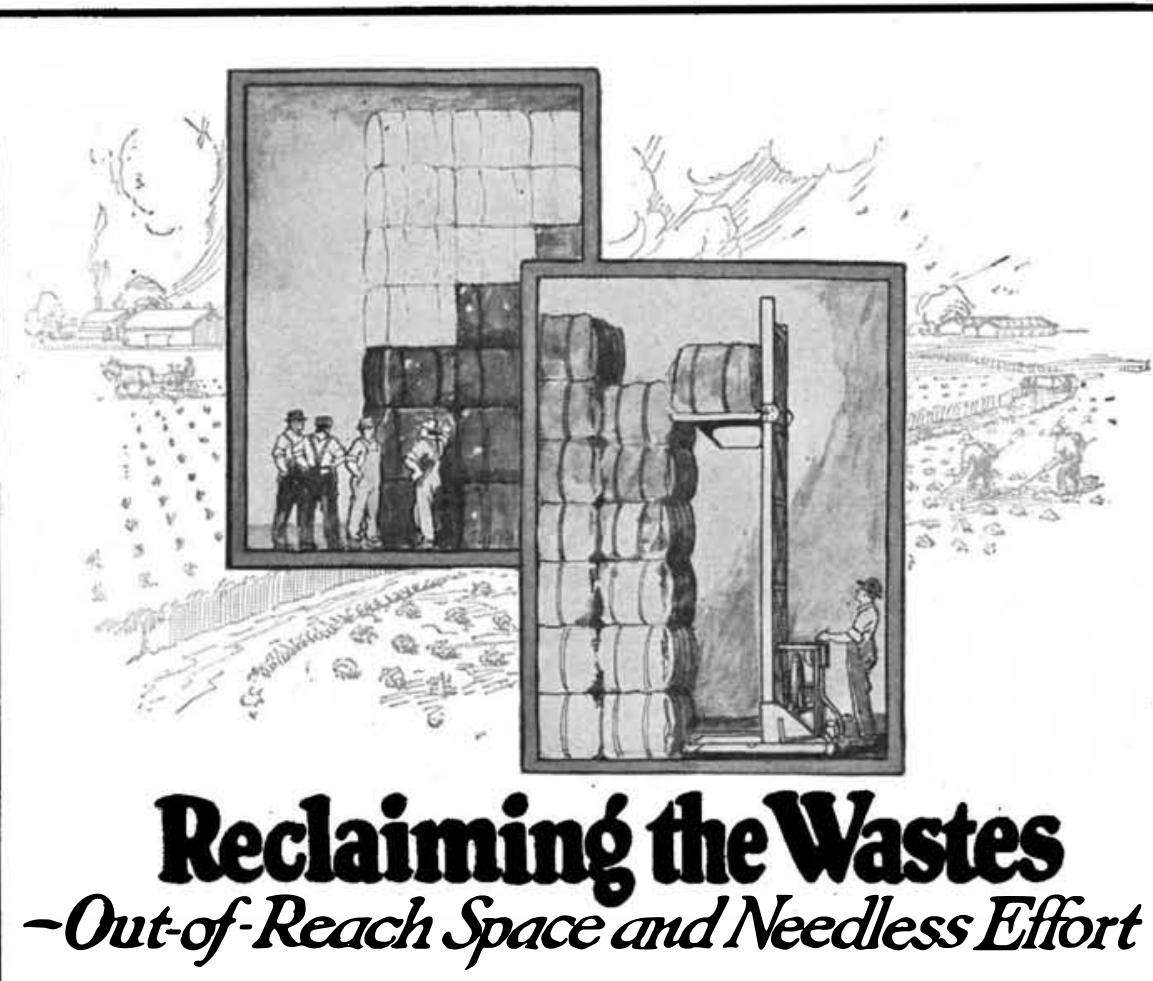

The vast desert areas of Western America are no more waste than are the inverted pyramids of unfilled spaces in warehouses. Nor more than the needless efforts of large crews of men struggling to pile packages in that space.

Scattered through thousands of storage rooms, these two-fold wastes go on unobserved, though combined they represent the loss of millions of dollars. Men seem not to realize that handreach methods are so expensive. Or, seeing this truth, they know no alternative.

But Economy Storage Engineers have both seen and remedied the wasteful practice. They have devised the Economy System of Storage Handling which brings highest points into easy reach and enables a few men to do what dozens heretofore could not accomplish.

Already many progressive concerns in nearly two hundred different industries are reclaiming their space and labor wastes by means of the Economy System of Storage Handling.

For more specifici information as to the application of this effir
ciency $3 y$ stem to your own businesse, write our Chicaso office ECONOMY ENGINEERING COMPANY 2643 W. Van Buren Street, Chicago, U. S. A. NEW YORK DETROIT ATLANTA SAN FRANCISCO Standard Steel Construction Co.. Canadian Mfrs.and Selling Agents, Port Robinson.Ont. See our exhibit at the Fifth National Exposition of Chemical Industries Coliseum and First Regiment Armory, Chicago, week of Sept. 22nd

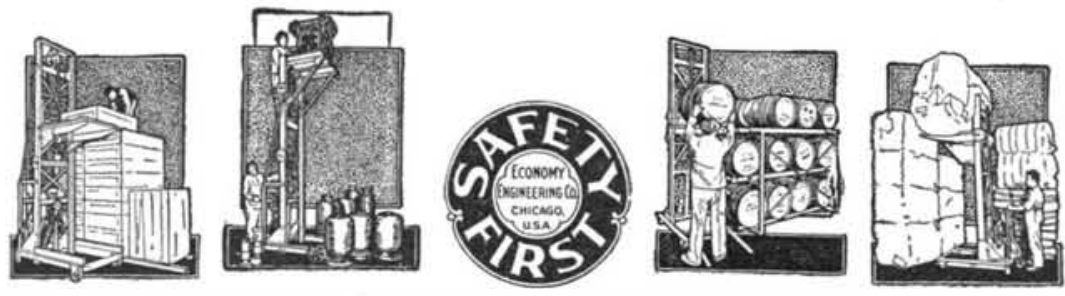

The Mark of Quality and Safety
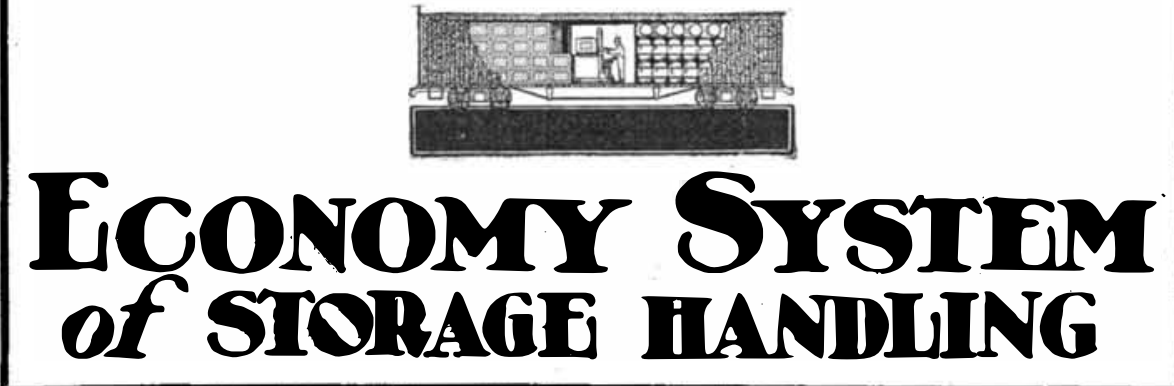